\title{
0 autorytecie Kościoła wychowujqcego na podstawie opinii i oczekiwań studentów oraz młodszych pracowników katolickiej uczelni
}

\author{
On the Authority of the Educating Church \\ according to the Opinions and Expectations \\ of Students and Younger Employees \\ of a Catholic University
}

\begin{abstract}
ABSTRAKT
Misja nauczycielska i wychowawcza Kościoła wymaga autorytetu. Autorytet Kościoła wpływa na skuteczność jego odziaływań wychowawczych. Opracowanie przedstawia wyniki ankietowych badań sondażowych i wywiadów fokusowych przeprowadzonych wśród studentów oraz pracowników naukowych uczelni katolickiej, dotyczq̨cych opinii na temat podstaw autorytetu Kościoła w Polsce, rodzaju posiadanego autorytetu, zmian (spadku) w zakresie autorytetu Kościoła i jego przyczyn, a także opinii na temat: Jak Kościół może budować swój autorytet, aby móc skuteczniej wychowywać? Badania pokazały, że według opinii ankietowanych nastapił spadek autorytetu Kościoła, a przyczyny tego sq złożone. Młodzi wierzqcy chcieliby pogłębienia więzi z Kościołem, oczekuja jednak większej otwartości Kościoła i poszanowania ich wolności.
\end{abstract}

SLOWA KLUCZOWE autorytet Kościoła, autorytet wychowawcy, spadek autorytetu, nadużycia autorytetu, wartości interpersonalne

\section{KEY WORDS}

the authority of the Church, the authority of the educator, the decline of authority, the abuse of authority, interpersonal values

SPI Vol. 20

2017/5/numer specjalny ISSN 2450-5358 e-ISSN 2450-5366 DOI: 10.12775/SPI.2017.5.005

II. Autorytet Kościoła w Polsce 


\begin{abstract}
The teaching and educational mission of the Church requires authority. The authority of the Church influences the effectiveness of its educational activities. The study presents the results of the research of questionnaire surveys and focus interviews conducted among students and academics of a Catholic university concerning their opinions about the foundations of the authority of the Church in Poland, the nature of this authority, the change (decrease) of the Church authority and the causes of this process, as well as opinions on how the Church can build her authority in order to be able to educate more effectively. Research has shown that in the opinion of the respondents, there has been a decrease in the authority of the Church and the reasons for that are complex. Young believers would like to deepen their relationship with the Church, but they expect the Church to be more open and respectful of their freedom.
\end{abstract}

\title{
Wprowadzenie
}

Autorytet Kościoła w społeczeństwie polskim jest znaczący, chociaż w jego ocenie następują dynamiczne zmiany. W czasach strajków i powstania oddolnego ruchu społecznego Solidarności katolickie społeczeństwo polskie, wspierane w nierównej walce o wolność i demokrację, doświadczało stabilnej siły Kościoła jako instytucji opierającej się działaniom aparatu socjalistycznego państwa, pomimo niezwykłej inwigilacji środowiska duchownych przez peerelowskie służby bezpieczeństwa. Kościół jawił się jako ostoja i wsparcie dla dążeń wolnościowych, a zarazem jako siła duchowa, czasem „cywilizująca” spontaniczny ruch społeczny. Nic dziwnego, że jego autorytet umacniał się, a oddziaływanie było znaczące.

Dzisiaj kontekst społeczny, ekonomiczny, kulturowy i polityczny zmienił się tak bardzo, że okoliczności kształtowania relacji między Kościołem a wierzącym (czyli między podmiotem a przedmiotem autorytetu, według terminologii J. Bocheńskiego ${ }^{1}$ ), w które wpisany jest autorytet, trzeba określać na nowo.

Przedstawiona $\mathrm{w}$ artykule analiza i interpretacja wybranych treści przeprowadzonych badań jest próbą odpowiedzi na pytanie: Jak ludzie

1 J. Bocheński, Sto zabobonów. Krótki filozoficzny stownik zabobonów, Kraków 1994, s. 25. 
wierzący postrzegają dzisiaj w Polsce autorytet Kościoła oraz jak oceniają rolę tego autorytetu w wychowawczych oddziaływaniach Kościoła? W kontekście tak sformułowanego problemu ważne były pytania o opinie dotyczące podstaw autorytetu Kościoła w Polsce, rodzaju posiadanego autorytetu, zmian (spadku) w zakresie autorytetu Kościoła ich jego przyczyn, oraz opinie na temat: Jak Kościół może budować swój autorytet, aby móc skuteczniej wychowywać?

Podejmując temat autorytetu w kontekście wychowawczych oddziaływań Kościoła w polskiej rzeczywistości, zdecydowałam się na zbadanie tych, którzy deklarują się jako wierzący. Nie interesowały mnie opinie przypadkowych osób, które nie mając wyrobionego zdania, ani doświadczenia kontaktów z duchownymi i społecznością praktykujących wiernych, zapewne powtarzałyby opinie słyszane w mediach czy potocznych dyskursach. Nie negując opiniotwórczego znaczenia mediów oraz wpływu środowiskowego na kształtowanie poglądów, chciałam poznać opinie tych, którzy przynajmniej w jakimś stopniu z wiarą i Kościołem się identyfikują. Praktycznym wymiarem tej identyfikacji może być studiowanie albo praca na katolickiej uczelni² ${ }^{2}$

\section{Autoryteł w kontekście wychowania}

Autorytet w ujęciu Stanisława Jarmoszki określony jest przez dwupodmiotowość, oddziaływanie interpersonalne, oraz przez afirmację jednego podmiotu przez drugi.

Jako rodzaj relacji interpersonalnej (społecznej) autorytet jest zjawiskiem wybitnie dwupodmiotowym. Współtworzy go podmiot uznawany jako autorytet oraz podmiot uznający go w takiej kategorii.

2 Badania metodą sondażu diagnostycznego $\mathrm{z}$ techniką ankiety przeprowadzono w czerwcu 2017 r. wśród studentów pedagogiki Akademii Ignatianum w Krakowie (90 osób). $Z$ racji specyfiki studiów pedagogicznych (a także większej niechęci mężczyzn do wypełniania kwestionariuszy) aż 92,2\% przebadanych stanowiły kobiety. Jak wykazała na podstawie badań Ewa Wysocka, płeć ma znaczenie dla religijności młodzieży, która wykazuje większą spójność w przypadku kobiet (por. E. Wysocka, Wymiary religijności mtodzieży w spoteczeñstwie ponowoczesnym, w: Katolicyzm polski na przetomie wieków, teologiczny, instytucjonalny i wspólnotowy wymiar Kościoła, red. J. Baniak, Poznań 2002, s. 182). Badania fokusowe przeprowadzono w serii 4 małych grup, które stanowili pracownicy naukowo-dydaktyczni Akademii Ignatianum, zatrudnieni na stanowisku asystenta albo adiunkta, posiadający tytuł magistra albo stopień doktora (Zakopane - Kraków, 12.06 - 8.07.2017). 
[...] Autorytet to zatem taka relacja, w której jedna strona budzi uznanie drugiej i stymuluje względem siebie zachowania i działania określające szeroko rozumianą afirmację, niewymuszone podporządkowanie i wzorowanie się lub traktowanie jako wzorcowego punktu odniesienia, czy też źródła znaczących inspiracji do aktywności (umysłowej czy praktycznej) ${ }^{3}$.

Autor ten wskazuje także, że istotna dla autorytetu jest "gotowość do podporządkowania się i rzeczywiste, niewymuszone podporządkowanie się woli podmiotu kreowanego na autorytet"4.

Definicje autorytetu wskazują na relację zależności i wpływu. Autorytet w procesie wychowania okazuje się być kluczowym, decyduje bowiem w dużej mierze o skuteczności, jaka jest wynikiem otwartości i akceptacji osoby poddanej procesom wychowawczym. „Relacja wychowanek - wychowawca w szczególny sposób oparta jest na autorytecie" ${ }^{5}$.

Analizując funkcje autorytetu, Ewa Wysocka wskazuje na autorytet jako wiarygodne źródło informacji, wzorów zachowań i postaw, ale także zaspokajania potrzeb bezpieczeństwa, akceptacji, poczucia własnej wartości. Na proces integracji tożsamościowej człowieka mają wpływ osoby znaczące, gdyż nie może ona zachodzić w próżni aksjologicznej6.

„Kościół instytucjonalny przywiązuje wielką rolę do własnej funkcji wychowawczej i nauczycielskiej, którą chce stale obejmować całą społeczność ludzi wierzących”7, pisze Józef Baniak. Dlatego dbałość o jakość własnego autorytetu jest dla Kościoła ważna.

3 S. Jarmoszko, Autorytet czy może wtadza - u podstaw nieporozumień, uproszczeń i mistyfikacji, w: Autorytet w wychowaniu i edukacji, red. D. Łażewska, Józefów 2013, s. 30.

4 Tamże, s. 14.

5 S. Gałkowski, Dtugomyślność. Wprowadzenie do flozofii wychowania, Kraków 2016, s. 204.

6 Por. E. Wysocka, Mtodzież a autorytety: analiza teoretyczna i empiryczne egzemplifikacje. Funkcjonowanie autorytetów w życiu codziennym mtodzieży szkót średnich a religijnośc, w: Mit autorytetu - autorytet mitu, red. J. Sieradzan, Białystok 2009, s. 288.

7 J. Baniak, Wprowadzenie, w: Katolicyzm polski na przetomie wiekórw, teologiczny, instytucjonalny i wspólnotowy wymiar Kościoła, red.J. Baniak, Poznań 2002, s. 10. 


\section{Podstawy autorytetu Kościoła}

Autorytet może mieć różne podstawy. Ze względu na nie Józef Bocheński wyróżnia dwa zasadnicze rodzaje autorytetu: epistemiczny, związany z wiedzą, doświadczeniem, kompetencjami oraz deontyczny, oparty na posiadanej władzy, przełożeństwie ${ }^{8}$. Ale są jeszcze inne podstawy, na których może być ugruntowany autorytet. Może on wywodzić się z „odziedziczonej po przodkach tradycji lub też z charyzmy, która jest źródłem uznania i naśladownictwa" ${ }^{\prime}$. Kościół w realizacji swej misji bazuje na różnych rodzajach autorytetu. Odwołuje się do Tradycji i wskazuje na jej ciągłość sięgającą świadectwa Apostołów. Swój autorytet opiera na także na prawdzie głoszonej Ewangelii. Zapytałam badanych studentów o ich opinie na ten temat. Pytanie wstępne miało charakter otwarty: „Na czym, w Pani/Pana ocenie, opiera się autorytet Kościoła (w Polsce)"? Okazało się ono niełatwe, część studentów je pominęła. Ci, którzy odpowiedzieli, najczęściej wskazywali na tradycję, a także na wiarę, jako fundamenty autorytetu Kościoła.

Część osób określało, jako podstawę tego autorytetu, osobę Jezusa Chrystusa. Wiele badanych pisało o tym, co Kościół „przekazuje”- bo na tym właśnie buduje swój autorytet: na przekazywanej tradycji, na przekazywanej nauce Jezusa, na przekazywanej Ewangelii. Nieliczni wskazywali także na ciągłość tradycji w przekazywanej wierze, jako uzasadnienie autorytetu. Złożoność fundamentu autorytetu Kościoła uchwyciła jedna ze studentek, definiując go następująco: „Autorytet Kościoła opiera się na tradycji, kulturze oraz Piśmie Świętym i zasadach wiary" (studentka, 20 lat).

Osobną grupę wypowiedzi stanowiły te, które wskazywały na różne osoby, począwszy od „zwykłych” księży, po papieży (Jana Pawła II, Franciszka), charyzmatycznych duchownych i świętych („na autorytecie Papieża, wiernych i niektórych duchownych" - studentka, 25 lat; „na słowach Pisma i życiu świętych” - student, 21 lat; „Jezusie i Papieżu Franciszku" - studentka, 22 lata).

Część badanych podkreślała, że budowanie autorytetu Kościoła dokonuje się poprzez realizowane zasady postępowania, naśladowanie Jezusa, tworzenie wspólnoty, przekazywanie wartości. Dla badanych

8 Por. J. Bocheński, Sto zabobonów, dz. cyt., s. 24.

9 P. Mazur, Wychowanie w czasach kryzysu autorytetu, „Zeszyty Społeczne KIK” 2011, s. 184. 


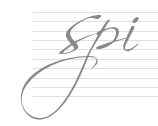

szczególnie ważne dla budowania autorytetu okazały się wartości interpersonalne: [właściwa] relacja do ludzi, dbanie o relacje międzyludzkie, szanowanie ludzi, pomaganie innym, opieka nad potrzebującymi, pomoc rodzinom.

Pojedyncze osoby uważały, że autorytet Kościoła opiera się „na władzy i hierarchii”, „na liczbie wiernych”. Kilka osób w odpowiedzi na to pytanie oceniło, że Kościół „nie ma autorytetu”.

Podobne pytanie powróciło w dalszej części kwestionariusza, już w wersji skategoryzowanej: „Jaki rodzaj autorytetu posiada Kościół (w Polsce)?”. Zdecydowane pierwszeństwo uzyskała odpowiedź „autorytet oparty na przekazywanej przez pokolenia tradycji”- wybrała ją więcej niż połowa badanych (63,3\% - badani mieli możliwość wyboru 1-3 odpowiedzi). Druga najczęściej wybierana odpowiedź brzmiała: „autorytet zapożyczony, pochodzący od głoszonej prawdy o Jezusie, od ewangelii" (38,8\%). Kolejne dwie odpowiedzi dotyczyły autorytetu etycznego i moralnego: ,autorytet moralny, oparty na głoszonych i realizowanych zasadach postępowania”(36,6\%), ,autorytet etyczny, oparty na głoszonych zasadach postępowania" (3,22\%). Stosunkowo mało osób upatrywało podstaw autorytetu Kościoła w hierarchii, pozycji i tytułach (15,5\%), w uznanej funkcji społecznej (13,3\%), a także posiadanej władzy (12,2\%). Z drugiej strony stosunkowo niewielu badanych (co piąty) uważa, że Kościół opiera swój autorytet na kompetencji, wiedzy, doświadczeniu, mądrości (17,8\%), czy na szczególnych zdolnościach, charyzmatach i umiejętności oddziaływania na ludzi (18,8\%).

Tabela 1.

Rodzaj autorytetu posiadanego przez Kościół katolicki w Polsce wg studentów uczelni katolickiej

\begin{tabular}{|l|c|c|}
\hline Rodzai aułoryłetu & N & $\%$ \\
\hline autorytet oparty na przekazywanei przez pokolenia tradycji & 57 & 63,3 \\
\hline autorytet zapożyczony, pochodzqcy od głoszonej prawdy o Jezusie, od ewangelii & 35 & 38,8 \\
\hline autorytet moralny, oparty na głoszonych i realizowanych zasadach postępowania & 33 & 36,6 \\
\hline autorytet etyczny, oparty na głoszonych zasadach postępowania & 29 & 32,2 \\
\hline $\begin{array}{l}\text { autorytet charyzmatyczny, oparty na szczególnych zdolnościach i umiejętności } \\
\text { oddziaływania na ludzi }\end{array}$ & 17 & 18,8 \\
\hline autorytet kompetencji, oparty na wiedzy, doświadczeniu, mqdrości & 16 & 17,8 \\
\hline autorytet hierarchiczny, oparty na pozycji, tyłułach & 14 & 15,5 \\
\hline autorytet społeczny, oparty na realizowanej, uznanei funkcji społecznei & 12 & 13,3 \\
\hline
\end{tabular}




\begin{tabular}{|l|c|c|}
\hline Rodzai autorytetu & N & $\%$ \\
\hline autorytet wypływajqcy z posiadanej władzy & 11 & 12,2 \\
\hline inny & 0 & 0 \\
\hline żaden z wymienionych & 1 & 1,1 \\
\hline Braki & 1 & 1,1 \\
\hline
\end{tabular}

Badani mogli wybrać $1-3$ odpowiedzi.

W wywiadach fokusowych z pracownikami naukowymi również w pierwszej kolejności wskazywano, że autorytet Kościoła jest oparty na przekazywanej tradycji. Następnie podkreślano jego autorytet etyczny i moralny. Zwrócono także uwagę na autorytet społeczny księży, ale tylko w małych miejscowościach. Badani mówili o znaczącym wpływie księży na sprawy społeczne w małych społecznościach. „W małych miejscowościach ksiądz to jest figura”, jego głos, zabrany w jakiejkolwiek sprawie, ma wpływ na działania ludzi. W ocenie badanych, wypowiedzi księży często mają charakter arbitralny, wygłaszają oni opinie w kwestiach społecznych nie oczekując dyskusji, natomiast ludzie (przynajmniej ich część) kierują się słowami duchownych.

\section{Zakres autorytełu Kościoła}

Zakres autorytetu polskiego Kościoła był przedmiotem kolejnych pytań. Wiązały się one z kompetencjami Kościoła i miały walor osobisty. „Czy dla Pani/Pana osobiście Kościół jest autorytetem w kwestiach gospodarczych, ekonomicznych, czy politycznych?”; „Czy dla Pani/Pana osobiście Kościół stanowi autorytet w kwestiach społecznych i moralnych?"

W odniesieniu do kwestii gospodarczych, ekonomicznych i politycznych badani nie byli tak jednomyślni, ich głosy były bardziej podzielone, przy czym przeważyły opinie negatywne. Ponad połowa nie uznaje w Kościele autorytetu w kwestiach gospodarczych, ekonomicznych i politycznych (nie - 26,7\%; raczej nie - 27,7\%). Ale autorytet taki potwierdziło mimo wszystko aż 38,9\% (tak - 16,7\%; raczej tak22,2\%). Kilka osób nie było zdecydowanych, jakiej udzielić odpowiedzi (trudno powiedzieć - 6,7\%). Tabela 2 ilustruje procentowy rozkład odpowiedzi. 
Tabela 2.

Kościół jako osobisty autorytet w kwestiach gospodarczych, ekonomicznych, albo politycznych

\begin{tabular}{|l|c|c|}
\hline Odpowiedzi: & $\mathbf{N}$ & $\%$ \\
\hline tak & 15 & 16,7 \\
\hline raczej tak & 20 & 22,2 \\
\hline trudno powiedzieć & 6 & 6,7 \\
\hline raczej nie & 25 & 27,7 \\
\hline nie & 24 & 26,7 \\
\hline Braki & 0 & 0 \\
\hline Ogółem & 90 & 100,0 \\
\hline
\end{tabular}

Ci, którzy uznają autorytet Kościoła w tych obszarach, uzasadniali go na kilka sposobów. Wśród uzasadnień dominowały te odwołujące się do osobistej wiary („wiara stanowi dla mnie podstawę życia, tote $\dot{z}$ staram się ją respektować na każdej płaszczyźnie”). Badani uzasadniali swoją odpowiedź, wskazując także na kulturę i tradycję („ponieważ Polska to kraj katolicki i bierze się pod uwagę naukę Kościoła”), na uniwersalny autorytet Kościoła („ponieważ Kościół jest jednym z najważniejszych autorytetów”, „bardzo często Kościół wypowiada się obiektywnie w tych kwestiach"), na potrzebę obecności wartości także w ekonomii i polityce (,ponieważ w tych kwestiach też powinny być brane pod uwagę normy etyczne i moralne”, „ze względu na przekazywane wartości”). Pojedyncze wypowiedzi określały także rolę Kościoła w odniesieniu do instytucji państwa („ponieważ w trudnych sytuacjach Kościół może wspomagać państwo”).

Józef Baniak, badając prestiż Kościoła w Polsce w czasach kryzysu i początków transformacji (lata 1984 i 1998), wykazał, że dominująca większość (74\%) badanych przyznała istnienie realnego wpływu Kościoła na sprawy kraju, a wielu $z$ nich uważało wówczas, iż jest to wpływ uzasadniony w sytuacjach trudnych, gdy władza świecka nie radzi sobie $\mathrm{z}$ istotnymi problemami narodu i państwa ${ }^{10}$. Jak pisze Janusz Mariański, przywołując Jana Szczepańskiego,

zdecydowane przeciwstawianie się komunizmowi [ze względu na narzucany ateizm] nadało polityczny wymiar religijności, a Kościołowi katolickiemu prestiż instytucji narodowej (argumentacja

10 J. Baniak, Prestiż Kościoła instytucjonalnego w Polsce a zmiana spoteczna. Studium socjologiczne, „Poznańskie Studia Teologiczne” t. 13, 2002, s. 172. 
religijna łączyła się z narodową). Kościół - zwłaszcza w latach osiemdziesiątych - sprawował opiekę polityczną i moralną nad opozycją w naszym kraju ${ }^{11}$.

Część dzisiejszego pokolenia młodych wydaje się być „spadkobiercami” tamtych przekonań, pomimo odmiennych realiów politycznych. $\mathrm{Z}$ drugiej strony rozwój demokratycznego społeczeństwa obywatelskiego sprawia, że wiele osób jest bardziej krytycznych i nie dostrzega potrzeby angażowania się Kościoła w sprawy polityczne i gospodarcze. Ponadto rozwój indywidualizmu powoduje stopniowy rozpad bardziej trwałych kiedyś porządków społecznych, w tym także religijnego ${ }^{12}$.

$\mathrm{Ci}$, którzy nie uznają autorytetu Kościoła w kwestiach gospodarczych, ekonomicznych, i politycznych, wskazywali przede wszystkim na brak kompetencji w tym zakresie. Pojedyncze osoby jako uzasadnienie wymieniały nadużycia finansowe księży oraz niepłacenie podatków.

W ramach wywiadów fokusowych $\mathrm{z}$ nauczycielami akademickimi badani także prezentowali dwie opinie, chociaż słabiej reprezentowana była ta uznająca autorytet Kościoła w materii gospodarczej, ekonomicznej, politycznej. Badani uważali wprawdzie, że głos Kościoła powinien być słyszalny na forum spraw publicznych, jako ważny głos w debatach, jednak stawiali określone warunki. Po pierwsze, stwierdzili, że głos duchownych nie powinien być przesądzający. W toku dyskusji przyznawali, że autorytet w kwestiach gospodarczych, ekonomicznych i politycznych może dotyczyć duchownych posiadających kompetencje w dyskutowanych materiach. Badani podkreślali też, w nawiązaniu do wypowiedzi duchownych w mediach, że niekompetentni nie powinni wypowiadać się w sposób autorytatywny.

W odniesieniu do kwestii społecznych i moralnych aż 65,6\% badanych uznaje w Kościele swój, osobisty autorytet (tak - 31,1\%, raczej tak-34,5\%). Ponadto dla niektórych Kościół stanowi na tym polu autorytet „czasami” (17,8\%). Zdanie przeciwne ma 13,3\% badanych (nie - 10,0\%; raczej nie-3,3\%). Tabela 3 ilustruje procentowy rozkład odpowiedzi.

11 J. Mariański, Kościót katolicki w spoteczeństwie obywatelskim, Lublin 1998, s. 22; J. Szczepański, Polskie losy, Warszawa 1993, s. 24 i 84 (za: J. Mariański).

12 Por. J. Mariański, Kościót instytucjonalny w Polsce - szanse i zagrożenia, w: Katolicyzm polski na przetomie wieków, teologiczny, instytucjonalny i wspólnotowy wymiar Kościota, red. J. Baniak, Poznań 2002, s. 41. 
Tabela 3.

Kościół jako osobisty autorytet w kwestiach społecznych i moralnych

\begin{tabular}{|l|c|c|}
\hline Odpowiedzi: & $\mathbf{N}$ & $\%$ \\
\hline tak & 28 & 31,1 \\
\hline raczej tak & 31 & 34,5 \\
\hline czasami & 16 & 17,8 \\
\hline trudno powiedzieć & 3 & 3,3 \\
\hline raczej nie & 3 & 3,3 \\
\hline nie & 9 & 10,0 \\
\hline Braki & 0 & 0 \\
\hline Ogółem & 90 & 100,0 \\
\hline
\end{tabular}

Ci, którzy uznają autorytet Kościoła w tych obszarach, uzasadniali go odwołując się przede wszystkim do własnej wiary, której praktyka dotyczy również wyborów moralnych („bo jestem osobą wierzącą”, ,ponieważ prawa kościelne są oparte na prawie Bożym. A ewangelie są dla mnie drogowskazem w relacji z drugim człowiekiem”). Niektórzy wskazywali na wychowanie, przekaz tradycji („bo Polska jest krajem katolickim”, „tak zostałam wychowana”, ,tak uczyli mnie rodzice i ja się z tym zgadzam").

Osoby, które nie uznają autorytetu Kościoła w kwestiach społecznych i moralnych, wskazują na różne przyczyny. Wśród nich powtarza się argument dotyczący nadużyć moralnych księży, braku zrozumienia dla człowieka („ponieważ coraz mniej Kościół stara się zrozumieć problemy ludzi, czasem z góry ocenia”), a nawet braku kompetencji („w wielu sprawach Kościół nie ma racji”). Wskazywano również na kontekst kulturowy („bo zanika szacunek dla Kościoła, wszystko kręci się wokół pieniądza a nie Boga”). Jako zastanawiające należy przywołać jedno z uzasadnień negatywnej odpowiedzi. Jako podważający jego autorytet moralny 21-letnia studentka uważa stosunek Kościoła do uchodźców, który ocenia jako nieroztropny.

\section{Spadek autorytetu i jego przyczyny}

Ważny aspekt badań dotyczył zmian zachodzących w zakresie autorytetu Kościoła. Odpowiedzi na pytanie postawione studentom nie pozostawiają złudzeń. Aż 70,0\% badanych oceniło, że autorytet ten 
zmalał, a 11,1\% ma problem z oceną („trudno powiedzieć”). Tabela 4 przedstawia procentowy rozkład otrzymanych odpowiedzi.

\begin{tabular}{|l|c|c|}
\hline Odpowiedzi: & $\mathbf{N}$ & $\%$ \\
\hline wzrósł & 5 & 5,6 \\
\hline pozostał na podobnym poziomie & 12 & 13,3 \\
\hline zmalał & 63 & 70,0 \\
\hline trudno powiedzieć & 10 & 11,1 \\
\hline Braki & 0 & 0 \\
\hline Ogółem & 90 & 100,0 \\
\hline
\end{tabular}

Tabela 4.

Ocena zmian w zakresie autorytetu Kościoła w Polsce w ostatnim czasie

Forma pytania nie przewidywała innych odpowiedzi, jednak kilka osób obok wybranej opcji: „zmalał” dopisało jeszcze inną odpowiedź: „nie ma autorytetu”. Jedna osoba wskazała też na przyczynę takiego stanu rzeczy, a jej osobista wypowiedź miała wydźwięk dramatyczny: „zmniejszył się przez upolitycznienie, dla mnie nie jest już autorytetem”.

Kluczowe dla poznania problemu spadku autorytetu Kościoła jest poznanie powodów zachodzących zmian. Ankietowanym postawiono zadanie samodzielnego określenia przyczyn obniżania się autorytetu Kościoła. W tym celu zadano dwa pytania. Pierwsze było sformułowane bardziej ogólnie: „Co osłabia/może osłabiać autorytet Kościoła w Polsce?”. Pytanie drugie dotyczyło osób: „Kto osłabia/może osłabiać autorytet Kościoła w Polsce?”. Wypowiedzi badanych, sformułowane w odpowiedzi na otwarte pytania, zostały następnie pogrupowane i skategoryzowane (niektórzy wskazali kilka czynników, dlatego odpowiedzi jest więcej niż badanych). Były one bardzo zróżnicowane. Niemniej jednak część odpowiedzi skupiała się wokół podobnych czynników i można było je pogrupować.

Najwięcej odpowiedzi odnosi się do niegodnych zachowań księży i duchownych, przy czym na pierwsze miejsce wysuwa się materializm: a) materializm, bogactwo, chciwość duchownych, bogacenie się kosztem wiernych (15,5\%). Poza materializmem wymieniano: b) zachowania księży, zły przykład księży, czyny wbrew wierze i nauce Chrystusa $(10,0 \%)$, c) księża pedofile, rozpusta księży, ukrywanie tuszowanie przestępstw duchownych, zakonnic (8,9\%), d) księża bez powołania (5,6\%), 
e) niemoralność księży, hipokryzja, kłamstwa (4,4\%), f) pycha, zadufanie, nonszalancja (3,3\%).

Druga i trzecia grupa przyczyn reprezentowana była przez taką sama liczbę odpowiedzi (10,0\%). Druga grupa wypowiedzi skupiała się na relacjach osobowych i komunikacji z duchownymi. Dotyczyły one podstawowych problemów z komunikacją oraz negatywnego nastawienia do człowieka: a) braku zrozumienia człowieka/wiernych, nieodpowiedniego przekazu wartości, języka używanego w Kościele $(5,6 \%)$, b) bardzo krytycznego oceniania ludzi, złego traktowania ludzi, nietolerancji $(4,4 \%)$.

Trzecia grupa wypowiedzi odnosiła się do nieadekwatnego dla duchownych zaangażowania politycznego (10,0\%): mieszania/łączenia polityki z religią, upolitycznienia, politycznych poglądów, lewicowych poglądów.

$\mathrm{Na}$ czwartym miejscu badani wskazywali „media” (7,8\%), wyjaśniając, że to one przyczyniają się do stopniowego obniżania autorytetu Kościoła. Na piątym miejscu znalazły się wypowiedzi tych, którzy uważają, że to politycy i rządzący przyczyniają się do spadku autorytetu: polityka, poglądy władzy inne od poglądów Kościoła, niedocenienie roli Kościoła przez polityków (5,6\%).

Miejsce szóste zajęły wypowiedzi dotyczące spadku liczby praktykujących i powołań: brak praktykujących osób, mało wierzących, mniej powołań $(4,4 \%)$. Na siódmym miejscu w tym rankingu przyczyn obniżania autorytetu Kościoła według ankietowanych znaleźli się sami wierzący: wierzący, którzy publicznie dają złe świadectwo/obrażają, lekceważą Kościół (3,3\%).

Co dziesiąta odpowiedź (10,0\%) dotyczyła przyczyn, które zostały wskazywane rzadziej. Pojedyncze odpowiedzi odnosiły się do kwestii kulturowych i rozwoju oraz celibatu, a także stosunku Kościoła do uchodźców (nienadążanie za biegiem czasu; brak rozwoju; to, że księża nie mają żon - nie mogą założyć rodziny; uchodźcy; liberalny stosunek do uchodźców). Ponadto były odpowiedzi bardzo ogólne albo nieprecyzyjne (negatywne wydarzenia; afery; niektóre zasady; niedocenienie roli Kościoła; niespójność; sekty - 6,7\%). Aż 23,3\% badanych nie sformułowało odpowiedzi (odpowiedź „nie wiem” albo brak odpowiedzi). Tabela 5 przedstawia procentowy rozkład wskazanych przez studentów przyczyn osłabiania się autorytetu Kościoła. 
Tabela 5. Czynniki osłabiajqce autorytet Kościoła w Polsce wg opinii studentów uczelni katolickiej

\begin{tabular}{|c|c|c|}
\hline Czynniki osłabiajq̨ce autorytet Kościoła w Polsce & $\begin{array}{c}\text { N (liczba badanych, } \\
\text { którzy sformuło- } \\
\text { wali odpowiedź) }\end{array}$ & $\%$ \\
\hline 1. Niegodne zachowania księży i duchownych & 43 & 47,7 (razem) \\
\hline a) materializm, bogactwo, chciwość duchownych, bogacenie się kosztem wiernych & 14 & 15,5 \\
\hline b) zachowania księży, zły przykład księży, czyny wbrew wierze i nauce Chrystusa & 9 & 10,0 \\
\hline $\begin{array}{l}\text { c) księża pedofile, rozpusta księży, ukrywanie tuszowanie przestępstw duchownych, } \\
\text { zakonnic }\end{array}$ & 8 & 8,9 \\
\hline d) księża bez powołania & 5 & 5,6 \\
\hline e) niemoralność księży, hipokryzja, kłamstwa & 4 & 4,4 \\
\hline f) pycha, zadufanie, nonszalancja & 3 & 3,3 \\
\hline 2. Problemy w komunikacji i relacjach interpersonalnych z duchownymi & 9 & 10,0 (razem) \\
\hline $\begin{array}{l}\text { a) brak zrozumienia człowieka/wiernych, nieodpowiedni przekaz wartości, } \\
\text { ięzyk używany w Kościele }\end{array}$ & 5 & 5,6 \\
\hline b) bardzo krytyczne ocenianie ludzi, złe traktowanie ludzi, nietolerancja & 4 & 4,4 \\
\hline 3. Nieadekwatne dla duchownych zaangażowanie polityczne & 9 & 10,0 \\
\hline \multicolumn{3}{|l|}{$\begin{array}{l}\text { mieszanie/łączenie polityki z religiq, upolitycznienie, polityczne poglądy, } \\
\text { lewicowe poglądy }\end{array}$} \\
\hline 4. Media & 7 & 7,8 \\
\hline 5. Politycy i rzqdzqcy & 5 & 5,6 \\
\hline \multicolumn{3}{|l|}{$\begin{array}{l}\text { politycy, poglądy władzy inne od poglądów Kościoła, niedocenienie roli } \\
\text { Kościoła przez polityków, }\end{array}$} \\
\hline 6. Spadek liczby prakłykujących i powołań & 4 & 4,4 \\
\hline \multicolumn{3}{|l|}{ brak praktykujących osób, mało wierzq̨cych, mniej powołań } \\
\hline 7. Sami wierzqcy & 3 & 3,3 \\
\hline \multicolumn{3}{|l|}{ wierzqcy którzy publicznie daja złe świadectwo/ obrażajq, lekceważq Kościół } \\
\hline 8. Inne odpowiedzi & 9 & 10,0 \\
\hline 9. Odpowiedzi zbył ogólne i nieprecyzyine & 6 & 6,7 \\
\hline 10. Brak odpowiedzi albo odpowiedź: nie wiem & 21 & 23,3 \\
\hline
\end{tabular}


Drugie z pytań, odnoszące się do przyczyn obniżenia autorytetu Kościoła, skupiało się na osobach („Kto osłabia/może osłabiać autorytet Kościoła w Polsce?”). Udzielone przez studentów odpowiedzi, jak można było przewidzieć na podstawie wyników wcześniejszego pytania, koncentrowały się na księżach i duchownych (42,2\% badanych udzieliło takiej odpowiedzi). Niektórzy wyszczególniali: „biskupi”, albo wskazywali nazwiska (szczególnie często przywoływana była osoba redemptorysty o. Tadeusza Rydzyka). Na drugim miejscu znaleźli się wierzący („wierzący”, „świeccy źle mówiący o Kościele”, „niepraktykujący”) i niewierzący („niewierzący oraz zrażeni do Kościoła”, „mający złe doświadczenia”), na trzecim miejscu politycy („politycy”, ,politycy lewaccy”, „rząd”, „władza”, „PiS”). Były też odpowiedzi bardzo ogólne, nieprecyzyjne („świat”, „ludzie”, „osoby nienadające się do pełnionych przez nie funkcji”, ,nieodpowiednie osoby wypowiadające się w mediach”).

Badania w grupach fokusowych (asystentów i adiunktów ze stopniem doktora lub tytułem magistra) dały jeszcze bardziej zróżnicowany obraz przyczyn stojących za obniżaniem się autorytetu Kościoła. Po pierwsze, badani zauważyli, że mimo generalnego spadku autorytetu Kościoła w społeczeństwie, księża mają wciąż bardzo silną pozycję w małych miejscowościach. Po drugie, chociaż wskazywano na nadużycia i problemy księży, to jednak ten czynnik obniżania autorytetu nie był tak dominujący, jak w przypadku badań ankietowych przeprowadzonych ze studentami. Wynika to zapewne z dojrzalszego spojrzenia. Badani mówili dużo o przemianach i problemach społeczno-kulturowych, a także o innej dzisiaj sytuacji politycznej. Jak mówili, kiedyś, w czasach strajków i Solidarności Kościół był ostoją wolności, wspierał Solidarność i dlatego miał duży autorytet, a dzisiaj sytuacja polityczna i społeczna jest dużo bardziej złożona. „Kościół był takim większym autorytetem kiedy byliśmy w zagrożeniu... z racji systemu. My się potrafimy jednoczyć [...], mamy taką cechę narodową, jeżeli jest zagrożenie jednoczymy się - wokół Kościoła, bo Kościół był wtedy silny, był autorytetem".

\section{Nadużycia autorytetu}

Problem osłabiania autorytetów ma ugruntowanie społeczno-kulturowe, wpływają nań procesy pluralizacji, indywidualizacji, a w kontekście 
religijnym także sekularyzacji oraz fenomen nowej duchowości (przesuniecie zainteresowania od zorganizowanych form religijności do duchowości $)^{13}$. Nie zmienia to faktu, że sami duchowni mają wpływ na to, że autorytety religijne, Kościoła i samych duchownych słabną i nie posiadają już takiego oddziaływania na życie społeczne.

Dodatkowo, w Polsce w ciągu ostatnich dwóch lat znacząco zmieniła się sytuacja społeczno-polityczna. Charakteryzuje się ona swoistą dychotomią. $Z$ jednej strony uwikłanie Kościoła w sprawy polityczne, otwarte popieranie rządzącej samodzielnie partii politycznej, zaowocowało większym wpływem Kościoła na sprawy polityczne, prawne oraz społeczne i zarazem większym poparciem (autorytetem?) u tych, którzy tę partie popierają. $Z$ drugiej strony wywołało to jeszcze większy opór i sprzeciw innej części społeczeństwa, która nie rozpoznaje w działaniach partii rządzącej oznak autentycznej katolickości, a dostrzega jedynie kultyczno-polityczne manifestacje oraz instrumentalne wykorzystywanie przychylności Kościoła jako kapitału politycznego. Dostrzega ponadto sprzeczność takiego zaangażowania Kościoła z zasadami wiary i przesłaniem ewangelii. To w efekcie znacząco wzmocniło spadek autorytetu Kościoła u tej części społeczeństwa polskiego, która uznała wykorzystanie autorytetu społecznego tej instytucji w celach politycznych za poważne nadużycie.

Józef Bocheński, pisząc o nadużyciach w zakresie autorytetu, podaje przykład osoby będącej autorytetem w pewnej dziedzinie, usiłującej wykazywać autorytet także w innych dziedzinach, w których go w istocie nie posiada. „Rozciąganie autorytetu na inne dziedziny jest typowym nadużyciem autorytetu"14. Tak wydaje się być w przypadku politycznego zaangażowania Kościoła i otwartego wspierania jednej partii politycznej. W konsekwencji Kościół może tracić autorytet moralny w dziedzinie swych kompetencji. Jest to niebezpieczne wystawianie autorytetu Kościoła na erozję. Społeczna krytyka bowiem dosięga nie tylko uzurpowanych kompetencji, ale stawia pod znakiem zapytania także

13 Por. J. Mariański, Religia w spoteczeństwie ponowoczesnym, Warszawa 2010, s. 139-219.

14 W. Banach, Zagadnienie autorytetu. O. Józefa Marii Bocheńskiego analiza problemu, „Filo-Sofija” 2013, 2(21), s. 155-156; J. Bocheński, Logika i filozofia. Wybór pism, opracował J. Parys, Warszawa 1993, s. 227. Jest to możliwe, ponieważ działa mechanizm, który każe uznającemu autorytet przyjąć, że ten, kto jest autorytetem musi być inteligentniejszy, potężniejszy, a zatem będzie miał także przewagę na innym polu. 
autorytet moralny, i to z dwojakiego powodu. Po pierwsze, osoby będące nosicielami autorytetu historycznego, opartego na tradycji, oraz autorytetu zapośredniczonego (tych, którzy przekazują ewangelię i życiem świadczą o niej) wydają się być niegodni, skoro uzurpują sobie dodatkowo inne zakresy autorytetu. Po drugie, u odbiorcy zachodzi podejrzenie, że skoro w jednym zakresie zachodzi uzurpacja, to może zachodzić także w innym. W praktyce oznacza to generalnie spadek autorytetu Kościoła.

Badani mają wobec duchownych wysokie oczekiwania; są to oczekiwania szczególne. Jak pisze Piotr Mazur:

W tradycji chrześcijańskiej uznaje się, że pełnia ludzkiego autorytetu nie przynależy do jakiegokolwiek wychowawcy, lecz urzeczywistnia się w doskonałym człowieczeństwie wcielonego Boga Jezusa Chrystusa, który jest „drogą, prawdą i życiem”. Wychowawca wobec Boga staje się niejako przeźroczysty, gdyż całą swoją osobą wskazuje na jedynego prawdziwego mistrza - Jezusa Chrystusa. Ostatecznie więc jego autorytet jedynie (aż) partycypuje w absolutnym autorytecie samego Boga jako Stwórcy świata i Zbawiciela człowieka ${ }^{15}$.

Potwierdziły to badania (referowane powyżej), w których respondenci wskazywali na rodzaj posiadanego przez Kościół autorytetu. Dwie najczęściej wybierane odpowiedzi (,autorytet oparty na przekazywanej przez pokolenia tradycji”- 63,3\%; , ,autorytet zapożyczony, pochodzący od głoszonej prawdy o Jezusie, od ewangelii” - 38,8\%) nie pozostawiają wątpliwości, co uważają oni za podstawę autorytetu Kościoła. To sprawia jednak, że autorytet wychowawcy chrześcijańskiego jest o tyle autorytetem, o ile jest on wierny swemu pierwowzorowi.

I właśnie w tym punkcie autorytet duchownych był najbardziej krytykowany przez badanych studentów. Zarzucali oni księżom życie niezgodne z powołaniem, życie „bez powołania”, materializm jako zaprzeczenie zasad życia ewangelicznego.

\section{Autoryteł wychowawczy Kościoła - jaki powinien być?}

Badania nad autorytetem Kościoła katolickiego w Polsce zmierzały do próby sformułowania wskazówek, które mogłyby stać się inspiracją

15 P. Mazur, Wychorwanie w czasach kryzysu autorytetu, dz. cyt., s. 192. 
i służyć do konfrontacji czy porównania z wyznaczanymi przez duchownych kierunkami potrzebnych zmian w zakresie oddziaływań wychowawczych i formacyjnych. W tym celu zapytano: Aby oddziaływanie Kościoła mogło być owocne, jakiego rodzaju autorytet jest potrzebny w Pani/Pana ocenie? Nie zakładałam, że badani będą obiektywnymi krytykami i doradcami, niemniej jednak ich głos jest niezwykle ważny, gdyż odzwierciedla refleksje wierzących wynikające z osobistych doświadczeń.

Odpowiedzi można podzielić na cztery grupy. Niektórzy wskazywali jeden z rodzajów autorytetów wymienionych na początku ankiety. Najczęściej jako potrzebny Kościołowi wymieniali oni autorytet moralny oraz charyzmatyczny („który pozwoli zgromadzić wokół siebie ludzi”). Niektórzy wymieniali jako potrzebny autorytet kompetencji i społeczny. Niemała grupa odpowiadających nawiązywała do wcześniejszego pytania o autorytet ujarzmiający i wyzwalający. Wszyscy oni wskazali na potrzebę posiadania przez Kościół autorytetu wyzwalającego ${ }^{16}$.

Pozostali rozumieli „autorytet” jako osobę i próbowali ją krótko scharakteryzować. Powtarzał się motyw księdza żyjącego swoim powołaniem: „księża z powołaniem, którzy są mega zaangażowani w to, co robią i kim są”. Inni zwracali uwagę na potrzebę osobowości charyzmatycznych („przydałby się przywódca charyzmatyczny”) oraz na świadectwo dawane życiem („oparty nie na słowach ale na czynach, swoim życiem pokazujący dobro”; „osoby dające, niezabierające, pomagające, uczciwe i żyjące w zgodzie z tym, co głoszą"). Inni koncentrowali się na cechach dotyczących relacji z wierzącymi („osoba słuchająca ludzi i ich potrzeb”, „nie oceniający a rozumiejący”). Pozostałe odpowiedzi miały charakter opisowy i udzielały rady, jaki powinien być Kościół, dlatego omówię je razem $z$ odpowiedziami na następne pytanie.

Drugie pytanie dotyczące oczekiwań wiernych wobec Kościoła oraz skuteczności jego wychowawczych oddziaływań, miało charakter zdania niedokończonego: Aby móc skuteczniej oddziaływać na postawy wierzących, Kościół w Polsce powinien... Forma pytania pozwoliła na większą swobodę wypowiedzi i projekcję oczekiwań badanych. Uzyskane odpowiedzi podzieliłam na kilka grup.

16 Problem autorytetu ujarzmiającego i wyzwalającego w wychowawczych oddziaływaniach Kościoła jest przedmiotem osobnego opracowania w ramach niniejszej monografii. 
Wypowiedzi sformułowane były albo pod adresem Kościoła jako całości, albo pod adresem duchownych, księży. Odpowiedzi sformułowanych negatywnie było mniej, niemniej pewna grupa studentów ograniczyła się do porad, czego Kościół nie powinien robić. Dotyczą one po pierwsze polityki, po drugie pieniędzy, a po trzecie postawy, zachowań i stylu życia. I tak, duchowni powinni „odciąć się od polityki”, „przestać łączyć swoje działania z polityką”, „nie angażować się w politykę”, „przestać narzucać poglądy polityczne w Kościele, nie dyktować co mamy myśleć” oraz „być niezależnym od sprawujących władzę”. Jedna rada dotyczy także tego, aby „nie narzucać praw religijnych za pomocą władzy politycznej"17.

W kwestiach materialnych duchowni powinni „mniej wagi przykładać do pieniędzy”, „żyć skromniej”, a także „pobierać mniej pieniędzy za [sic!] sakramenty”. Jeden z badanych zaleca, aby „wprowadzić reformy związane z finansami”. Nie wyjaśnia jednak, na czym miałyby one polegać.

W odniesieniu do postaw i zachowań duchownych, badani krytykują roszczeniowość księży i żądanie specjalnych przywilejów, a także nadmierny krytycyzm i brak zrozumienia ludzi.

Wypowiedzi sformułowane pozytywnie podzieliłam na dotyczące: 1) relacji Kościoła/duchownych do świata; 2) relacji do innych ludzi (szczególnie rozbudowana grupa wypowiedzi); 3) świadectwa dawanego życiem; 4) postaw; 5) głoszonych treści i źródeł wiary, oraz pozostałe.

\section{Relacja do świata - żyć w XXI wieku}

Według badanych, Kościół powinien „otworzyć się na XXI wiek”, „żyć w XXI wieku”, „nieoderwany od realiów”, powinien umieć „dostosować się" do zmieniającego się świata, jednak nie porzucając tego, co ważne. Jak piszą badani, Kościół powinien „być otwarty na współczesny świat, a jednocześnie żyć wartościami”. Ale także „powinien rozumieć dzisiejsze czasy i nie szukać wszędzie zła, dostrzegać więcej opcji”. Także wobec wiernych powinien być bardziej otwarty, „mieć postępowe podejście do wiernych”, „rozumieć współczesny świat, być zorientowanym we wszystkich aspektach i dążyć do poprawy społeczeństwa”.

17 Nie przytaczam odpowiedzi podobnych i powtarzających się. 


\section{Relacja do ludzi - otwartość w kontaktach, przystępność}

Relacje z ludźmi zajmują najwięcej miejsca wśród sformułowanych odpowiedzi. Badani szczegółowo określają podstawowe trudności, na jakie napotykają w kontaktach z duchownymi. Poważny problem w zakresie relacji duchownych z ludźmi dotyczy ich zamknięcia, nieprzystępności. Kościół według wielu badanych powinien „być bardziej otwarty na człowieka/ludzi”, „wyjść do ludzi”.

Młodzi zauważają, że Kościół powinien „być przystępny dla młodych ludzi”, mają także postulaty dotyczące formacji księży: należy „kształtować postawy duchownych, aby ludzi świeckich nie zniechęcali do kontaktu ze sobą”. Dostrzegają nienaturalność i schematyzm w zachowaniach duchownych.

\section{Relacje do ludzi - starać się rozumieć, proponować a nie narzucać}

Główny problem dotyczy jednak niezrozumienia ze strony duchownych i pewnej ich zaborczości, narzucania z góry określonych zasad i rozwiązań, co nie prowadzi do wewnętrznego rozwoju moralnego, ale do infantylnego podporządkowania sobie wierzących. Studenci oczekują głębszego procesu komunikacji i przekazu treści religijnych, opartego na uwzględnieniu i poszanowaniu ich wolności wyboru. Kościół według badanych „nie [może] być tak konserwatywny i zaborczy, powinien rozumieć i nauczać”, „powinien pokazywać różne drogi życia a nie tylko nakazywać jak żyć”, „przekonywać a nie nakazywać”, „starać się rozumieć, nie nakazywać a proponować”.

\section{Relacja do ludzi - głębsza, ludzkie podejście do człowieka}

Badani sugerują nie tylko większą otwartość. ale także zainteresowanie nimi, a nawet pewne zbliżenie (,interesować się wierzącymi”, „wychodzić do ludzi, spróbować zrozumieć człowieka”), indywidualne podejście („do każdego człowieka podchodzić indywidualnie”) i „ludzkie traktowanie” („bardziej «po ludzku» podchodzić do osoby”).

Co ważne, respondenci sygnalizują potrzebę głębszej relacji. Według nich duchowni powinni „być bliżej ludzi”, „starać się nawiązywać głębszy kontakt z wiernymi, spróbować wczuć się w ich sytuację”, „łączyć, jednoczyć się z wiernymi”. Autentyczne zainteresowanie i głębsza relacja prowadzi do wsparcia wierzących, którego potrzebują („bardziej otworzyć się na problemy ludzi i naprawdę starać się im pomóc”, 
„pomagać ludziom w trudnych chwilach”, „wspierać wierzących, dawać im wewnętrzną siłę").

\section{Świadectwo - autentyzm i wiarygodność}

Druga pod względem liczebności grupa wypowiedzi dotyczyła świadectwa dawanego życiem (przez duchownych). Często powtarzało się wymaganie wiarygodności. Ksiądz powinien być „wiarygodny”, "godny zaufania wierzących”. Aby to osiągnąć, musi „żyć w zgodzie z tym, co głosi”, „sam reprezentować głoszone prawdy”. Jeden z badanych zaznacza, że „potrzebny jest ktoś, kto będzie postępował zgodnie z wyznawanymi wartościami, których naucza”. Inni wskazują podobne przymioty, jakich żąda się od autorytetu nauczającego: „musi być wzorem”, „stawać na jasnych pozycjach, być w nich spójny”, „nieudający”, „szczery, charyzmatyczny”, ,autentyczny i bardziej bezinteresowny”, „musi być wiarygodny i przystępny dla ludzi”.

\section{Postawa - pomagać i służyć}

Powyższe wymagania łączą się wprost z postawą ludzi Kościoła. Według badanych Kościół z autorytetem to „taki, który pomaga, prowadzi, pokazuje drogę a nie taki, który karci, zakazuje, a zamiast pouczyć i okazać miłosierdzie to skreśla”, to „Kościół dla ludzi”, który charakteryzuje się „postawą służącą”. Kościół, któremu w oczach wierzących należy się szacunek, to Kościół otwarty, pokorny i skromny.

\section{Głoszone treści i źródła wiary - głosić proste słowo Boże}

Oczekiwania wiernych wobec Kościoła dotyczą także istoty jego misji, głoszonych treści i źródeł wiary. Wierni zalecają swoiste nawrócenie i postulują: „wrócić do pierwotnych celów i dążeń”, „żyć zgodnie z nauką Kościoła i ewangelii”, „nie oceniać ale świadczyć swoim życiem jak wielkie jest miłosierdzie Pana Jezusa”. Wydaje się, że niektórym brakuje podstawowego przekazu wiary w Kościele, zalecają bowiem „więcej mówić o prawdach wiary, zawartych w Biblii, o radosnym chrześcijaństwie”, „głosić proste słowo Boże”.

Pozostałe, nieliczne odpowiedzi odbiegały od innych. Jeden z badanych postulował „postawić na angażowanie wierzących we wspólnotę”, „większe propagowanie dzieł Kościoła”, ktoś inny uważa, że Kościół powinien „być bardziej restrykcyjny”, „mieć większy wpływ na 
moralność ludzi”, ale zarazem inna osoba, zaleca: „poprawić i pilnować [sic!] moralności duchownych".

Również w ramach badań fokusowych dyskutujące grupy podejmowały temat autorytetu Kościoła wychowującego: Jak Kościół może budować swój autorytet, co powinien robić, aby móc skuteczniej wychowywać? Badani podejmowali różne wątki, będąc zgodni, że autorytet Kościoła tworzą konkretni ludzie, „spójni, życzliwi i otwarci na problemy ludzi, nie tylko te, takie zwykłe, ale też takie, które wiążą się z życiem poza wiarą, poza religią - Kościół nie powinien się na nich zamykać, ich odrzucać, ale powinien różnymi sposobami ich zachęcać”. To „ludzie prawdziwi, którzy identyfikują się z Kościołem, identyfikują się z dekalogiem i tym, co ten dekalog wnosi do życia społecznego". Co do działań Kościoła podejmowanych w celu skutecznych oddziaływań wychowujących, badani wymieniali różne. Uważają, że Kościół powinien „nadążać za czasem” a zarazem „odczytywać znaki czasu”. Mówili o Piśmie świętym, o źródłach, z których musi częściej czerpać ksiądz, kiedy zwraca się do wiernych. Zwrócili uwagę na życie duchowe, które jest podstawą podejmowania przez wierzących wyzwań i wysiłku życia zgodnego z przyjmowanymi religijnymi wzorami. Jeden $z$ badanych podkreślit, że „tradycja sama nie wystarczy. Jak mówił Karl Rahner, chrześcijanie w XXI wieku albo będą mistykami, albo ich w ogóle nie będzie. Bo bez tego Kościół nie ma nic do zaoferowania. Może stać się organizacją społeczną, ale to nie jest jego misja”. Najczęściej jednak podejmowali kwestie relacji duchownych z wierzącymi, ich postaw, mówili o tym, jak ważne jest „żeby być przyjacielem, otwartym na drugiego człowieka, każdego człowieka”, „wychodzić z miłością do drugiego człowieka”.

Poruszano także trudne problemy celibatu duchownych, duszpasterstwa w społecznościach LGBT. Dyskusje te nie prowadziły do konsensusu, były wyraźne rozbieżności, jednak badani zgadzali się co do jednego, że działania i postawy osób duchownych są bardzo ważne i są znakiem tego, jak Kościół generalnie podchodzi do człowieka. Podkreślali, że to podejście i postawę duchownych względem człowieka widać szczególnie wyraźnie w kontekście spraw trudnych i kontrowersyjnych.

Podsumowując można ocenić, że głosy dyskutujących pracowników naukowych korespondowały z tym, co wyrazili ankietowani studenci, a jako bardziej wyważone i rozumiejące stanowiły zarazem uzupełnienie i pogłębienie. 


\section{Konkluzja}

Przeprowadzone badania miały za cel odpowiedź na pytanie: Jak ludzie wierzący postrzegają dzisiaj w Polsce autorytet Kościoła oraz jak oceniają rolę tego autorytetu w wychowawczych oddziaływaniach Kościoła?

Autorytet Kościoła, według badanych, zbudowany jest na tradycji i zapożyczony od głoszonej ewangelii i prawdy o Jezusie Chrystusie. Jest także autorytetem etycznym i moralnym, opartym na głoszonych i realizowanych zasadach postępowania. W odniesieniu do kwestii społecznych i moralnych $2 / 3$ badanych uznaje albo skłania się do uznawania autorytetu Kościoła. W odniesieniu do kwestii gospodarczych, ekonomicznych i politycznych badani są podzieleni, wprawdzie ponad połowa nie uznaje takiego autorytetu, ale jednocześnie uznaje go aż 38,9\% ankietowanych. Można wnioskować, że jest to odzwierciedlenie aktualnej złożonej sytuacji społecznej, politycznej i religijnej w państwie, którą wyznaczają głęboki podział społeczeństwa na tle politycznym oraz identyfikacja Kościoła z jedną ze stron politycznego konfliktu, który angażuje i antagonizuje większość społeczeństwa.

W ocenie zmian w zakresie autorytetu Kościoła badani byli jednomyślni, aż 70\% potwierdziło spadek autorytetu, a tylko 5,6\% oceniło, iż nastąpił jego wzrost. Ocena przyczyn tego spadku jest zgodna z wynikami badań socjologów dotyczącymi oceny Kościoła w społeczeństwie $^{18}$. Jako przyczyny najczęściej wskazywano zachowania duchownych, ich materializm i chciwość, zaangażowanie polityczne i narzucanie politycznych poglądów, życie wbrew powołaniu i głoszonym ideałom, niemoralność, hipokryzję.

18 J. Mariański, Postawy Polaków wobec Kościota Katolickiego - analiza socjologiczna, „ZN KUL” 2014, 57, nr 1 (225), s. 81-106; J. Mariański, Emigracja mtodzieży polskiej z Kościota?, „Keryks” 2009, Nr 8, s. 193-223; J. Baniak, Kościót instytucjonalny w krytycznym spojrzeniu dzisiejszych katolików polskich (I), „Przegląd Religioznawczy” 2011, nr 2 (240), s. 91-114; J. Baniak, Zagubiony Kościót (część II, dokończenie), ,Res Humana” 2016, nr 1, s. 28-31; J. Baniak, Religia katolicka i Kościót rzymskokatolicki w opiniach polskiej mtodzieży. Od akceptacji do kontestacji, Kraków 2015; A. Potocki, Mtodzież o Kościele - krytycznie i z dystansem, w: Katecheza w Kościele i dla Kościota, red. R. Czekalski, Płock 2006, s. 283-303; I. Borowik, Stosunek mtodzieży do Kościota rzymskokatolickiego w Polsce w perspektywie wyrwiadów biograficznych, „Socjologia Religii” 2005, t. 3, s. 149-167. 
Z drugiej strony, krytyka dotyczyła zasadniczych problemów w komunikacji i relacjach interpersonalnych z duchownymi: braku zrozumienia dla człowieka żyjącego we współczesnym świecie, zbyt krytycznego oceniania a także złego traktowania ludzi, nietolerancji, nieodpowiedniej formy przekazu, języka używanego w Kościele.

Wypowiedzi otwarte studentów dotyczące oceny przyczyn spadku autorytetu Kościoła sygnalizowały zarazem stawiane przez nich Kościołowi wymagania, które następnie potwierdzone zostały przez odpowiedzi na dalsze pytanie - dotyczące oczekiwań. Oczekiwania i sugestie badanych studentów dotyczące budowania autorytetu przez Kościół skupiały się w dużej mierze właśnie na kwestiach dotyczących relacji z duchownymi.

Warto w tym miejscu zauważyć, że przedstawiciele instytucjonalnego Kościoła mają poczucie oddalenia młodych od Kościoła. Ks. Andrzej Offmański pisze, że „Pogłębiona wizja Kościoła domaga się te $̇$ zasadniczej korekty w koncepcji wychowania młodego pokolenia do życia w Kościele. Domaga się położenia większego nacisku na ożywienie poczucia przynależności do Kościoła i zacieśnienie więzi młodych z Kościołem partykularnym [...]"19. Uderza w tym zdaniu użycie słowa „nacisk”w kontekście zwrotów „zacieśnienie więzi” czy „ożywienie poczucia przynależności”. Niezręczność sfomułowania wypowiedzi jest znacząca, odsłania bowiem nieadekwatność podejmowanych działań, mimo świadomości problemu.

Aby móc uznawać autorytet Kościoła, młodzi wymagają od niego nie tylko kompetencji ale także przystępności, większej otwartości. Zamiast konserwatyzmu i zaborczości oczekują zrozumienia i przekazu treści z poszanowaniem ich wolności. Dostrzegają sztuczność niektórych zachowań księży, schematyzm w podejściu do rozwiązywania problemów, oderwanie od realiów rzeczywistości, które uniemożliwiają prawdziwą komunikację. Wielu młodych oczekuje autentycznej relacji, którą rozumieją jako opartą na indywidualnym podejściu, na zrozumieniu i zainteresowaniu ich życiem, osobistą sytuacją. Młodzi oczekują prawdziwych, to znaczy głębokich relacji z duchownymi, w ramach których chcą, aby szanowano ich wolność i godność. Te oczekiwania wydają się być nowym zjawiskiem, gdyż w prowadzonych dotąd badaniach dominowała niechęć wobec duchownych, jako zbyt

19 A. Offmański, Mtodzież a Kościót - relacje mtodzieży względem Kościota, w: Katecheza w Kościele i dla Kościoła, red. R. Czekalski, Płock 2006, s. 49. 
konserwatywnych, restrykcyjnych, narzucających swoje zdanie i swoją wolę $e^{20}$.

Badani studenci nie tylko sugerują Kościołowi większą otwartość, ale są zainteresowani zbliżeniem z Kościołem. Czyżby zatem młodzi postanowili dać szansę Kościołowi? Być może ta postawa wynika ze zmieniających się realiów społeczno-kulturowych, pozwalających ludziom na większą otwartość, bezpośredniość i sprawiających zarazem, że nie czują się już oni tak zdominowani przez zewnętrzne autorytety. Zapewne również specyfika grupy badawczej, którą stanowili studenci uczelni katolickiej, studiujący pedagogikę, wpłynęła na formułowane postulaty w zakresie budowania autorytetu Kościoła i owocnych oddziaływań wychowawczych.

Dobrym znakiem, mimo obniżającego się autorytetu Kościoła, są oczekiwania młodych wierzących dotyczące głębszej relacji, kierowane do duchownych. Młodzi wierni dorastający w kulturze otwartej są dzisiaj partnerami dla duchownych, oczekują ich szacunku i otwartości. Jest to poważne wyzwanie dla Kościoła.

\section{Bibliografia}

Banach W., Zagadnienie autorytetu. O. Józefa Marii Bocheńskiego analiza problemu, „Filo-Sofija” 2013, 2(21), s. 151-157.

Baniak J., Kościót instytucjonalny w krytycznym spojrzeniu dzisiejszych katolików polskich (I), „Przegląd Religioznawczy”2011, nr 2 (240), s. 91-114.

20 Por. J. Mariański, Religia w społeczeństwie ponowoczesnym, dz. cyt., s. 101-106; J. Baniak, Kościót instytucjonalny w krytycznym spojrzeniu dzisiejszych katolików polskich (I), dz. cyt., s. 91-114; J. Baniak, Portret księdza w wyobrażeniach i ocenach polskiej mtodzieży. Studium socjologiczne, Kraków 2013; J. Baniak, Religia katolicka i Kościót rzymskokatolicki w opiniach polskiej mtodzieży, dz. cyt.; A. Potocki, Mtodzież o Kościele - krytycznie i z dystansem, dz. cyt., s. 283-303; A. Potocki, Dlaczego mtodzież boi się Kościota?, „Socjologia Religii” 2005, t. 3, s. 167-182; I. Borowik, Stosunek mtodzieży do Kościota rzymskokatolickiego..., dz. cyt., s. 149-167. Już w 1997 r. na podstawie wyników badań J. Mariański pisał: „Według opinii wielu ludzi w Polsce aktywna obecność Kościoła w życiu publicznym niesie ze sobą niebezpieczeństwo zagrożenia swobody działania jednostek i grup społecznych, stanowi ograniczenie swobody wyboru. Po okresie ucisku rządów totalitarnych niezależność od zewnętrznych nacisków jest ceniona wysoko [...]". J. Mariański, Religia i Kościót między tradycją i ponorwoczesnościq - studium socjologiczne, Kraków 1997, s. 240. 
Baniak J., Portret księdza w wyobrażeniach i ocenach polskiej mtodzieży. Studium socjologiczne, Nomos, Kraków 2013.

Baniak J., Prestiz Kościota instytucjonalnego w Polsce a zmiana spoteczna. Studium socjologiczne, „Poznańskie Studia Teologiczne” t. 13, 2002, s. 153-195.

Baniak J., Religia katolicka i Kościót rzymskokatolicki wopiniach polskiej mtodzieży. Od akceptacji do kontestacji, Nomos, Kraków 2015.

Baniak J., Wprowadzenie, w: Katolicyzm polski na przetomie wieków, teologiczny, instytucjonalny i wspólnotowy wymiar Kościota, red. J. Baniak, UAM, Poznań 2002, s. 7-11.

Baniak J., Zagubiony Kościót (część II, dokończenie), „Res Humana” 2016, nr 1, s. 28-31.

Bocheński J., Logika i filozofia. Wybór pism, opracował J. Parys, Wydawnictwo Naukowe PWN, Warszawa 1993.

Bocheński J., Sto zabobonów. Krótki filozoficzny stownik zabobonów, Wydawnictwo Philed, Kraków 1994.

Borowik I., Stosunek mtodzieży do Kościota rzymskokatolickiego w Polsce w perspektywie wywiadów biograficznych, „Socjologia Religii” 2005, t. 3, s. 149-167.

Jarmoszko S., Autorytet czy może wtadza - u podstaw nieporozumień, uproszczeń $i$ mistyfikacji, w: Autorytet w wychowaniu i edukacji, red. D. Łażewska, Wydawnictwo WSGE, Józefów 2013, s. 22-57.

Mariański J., Emigracja mtodzieży polskiej z Kościota?, „Keryks” 2009, nr 8, s. 193-223.

Mariański J., Kościót instytucjonalny w Polsce - szanse i zagrożenia, w: $K a-$ tolicyzm polski na przetomie wieków, teologiczny, instytucjonalny i wspólnotowy wymiar Kościota, red. J. Baniak, UAM, Poznań 2002, s. 41-71.

Mariański J., Kościót katolicki w spoteczeństwie obywatelskim, Redakcja Wydawnictw KUL, Lublin 1998.

Mariański J., Postawy Polaków wobec Kościota Katolickiego - analiza socjologiczna, „ZN KUL” 2014, 57, nr 1 (225), s. 81-106.

Mariański J., Religia i Kościót między tradycją i ponowoczesnościa - studium socjologiczne, Nomos, Kraków 1997.

Mariański J., Religia w spoteczeństwie ponowoczesnym, Oficyna Naukowa, Warszawa 2010.

Mazur P., Wychowanie w czasach kryzysu autorytetu, „Zeszyty Społeczne KIK”2011, s. 183-192.

Offmański A., Mtodzież a Kościót - relacje mtodzieży względem Kościota, w: Katecheza w Kościele i dla Kościota, red. R. Czekalski, Płocki Instytut Wydawniczy, Płock 2006, s. 37-51.

Potocki A., Dlaczego mtodzież boi się Kościota?, „Socjologia Religii” 2005, t. 3, s. 167-182.

Potocki A., Mtodzież o Kościele - krytycznie i z dystansem, w: Katecheza $w$ Kościele i dla Kościota, red. R. Czekalski, Płocki Instytut Wydawniczy, Płock 2006, s. 283-303. 
Szczepański J., Autorytet w nauce, w: Autorytet w nauce, red. P. Rybicki, J. Goćkowski, Ossolineum, Wrocław 1980, 13-18.

Wysocka E., Wymiary religijności mtodzieży w spoteczeństwie ponowoczesnym, w: Katolicyzm polski na przetomie wieków, teologiczny, instytucjonalny i wspólnotowy wymiar Kościota, red. J. Baniak, UAM, Poznań 2002, s. 167-184.

Wysocka E., Mtodzież a autorytety: analiza teoretyczna i empiryczne egzemplifikacje. Funkcjonowanie autorytetów w życiu codziennym mtodzieży szkót średnich a religijność, w: Mit autorytetu - autorytet mitu, red.J. Sieradzan, Wydawnictwo Uniwersytetu w Białymstoku, Białystok 2009, s. $285-322$.

\section{ADRES DO KORESPONDENCJI:}

Dr hab. Renata Jasnos, prof. AIK

Akademia Ignatianum w Krakowie

e-mail: renata.jasnos@ignatianum.edu.pl 